Заболотний О. А., к.військ.н., доцент (ORCID ID 0000-0001-8020-4721);

Зельницький А. М., к.пед.н., професор (ORCID ID 0000-0002-3910-7329);

Оліферук В. М. (ORCID ID 0000-0002-0722-7561)

Центр воєнно-стратегічних досліджень Національного університету оборони України імені Івана Черняховського, Київ

\title{
Формування кадрового потенціалу Збройних Сил України в системі вищої військової освіти: теоретичні аспекти
}

Резюме. У статті розглянуто теоретичні аспекти формування кадрового потенціалу Збройних Сил України та якості підготовки, перепідготовки і підвищення кваліфікації офіцерських кадрів у системі вищої військової освіти.

Ключові слова: кадровий потенціал Збройних Сил України; система вищої військової освіти; якість підготовки офіцерських кадрів.

Постановка проблеми. Одним 3 пріоритетних напрямів державної політики у сфері національної безпеки ї оборони України $\epsilon$ формування i нарощування кадрового потенціалу Збройних Сил України (далі 3СУ). Ядро кадрового потенціалу 3СУ складають офіцерські кадри. Їх підготовка, перепідготовка i підвищення кваліфікації здійснюється переважно в системі військової освіти (далі - CВО). Провідними у цьому питанні є вищі військові навчальні заклади та військові навчальні підрозділи закладів вищої освіти (далі - ВВН3). Саме на них покладається відповідальність за виконання державного замовлення щодо підготовки офіцерів, де якісні показники є вирішальними.

Проблема якості підготовки_офіцерських кадрів набула особливої актуальності упродовж останніх кількох років. Її загострення було зумовлене низкою чинників. Особливо щодо рівня готовності офіцерів до ведення бойових дій в зоні антитерористичної операції (АТО), який виявився недостатнім i значною мірою невідповідним потребам ЗСУ. Це, здебільшого, виявилось на початковому етапі АТО, в якому віддзеркалилися певні прорахунки щодо розвитку оборонної сфери держави, Збройних Сил України, а також системи військової освіти. Водночас i на сьогодні залишається актуальною потреба у комплексному та оперативному розв’язанні накопичених роками проблем. Це повною мірою стосується ефективності функціонування $\mathrm{CBO}$, що потребує проведення подальших теоретичних досліджень у сфері військової освіти, удосконалення iіi нормативно-правової бази, а головне - розроблення i впровадження в педагогічну практику ВВНЗ політики забезпечення і гарантування якості підготовки військових фахівців.

Аналіз останніх досліджень i публікацій. Загальним проблемам формування кадрового потенціалу присвячено наукові праці вітчизняних вчених: Л. В. Беззубка, Б. І. Беззубка, Л. О. Гончарової, .М.Дашка, А. Ю. Савченка та ін. Щодо формування та нарощування кадрового потенціалу Збройних Сил України, то основні підходи до розв’язання цієї проблеми викладено у документах оборонного планування: Стратегічному оборонному бюлетені України (далі - СОБ) та Державній програмі розвитку Збройних Сил України (далі - ДПР ЗСУ) на період до 2020 року, Концепції військової кадрової політики у Збройних Силах України, а також наукових працях відомих військових учених, зокрема О. М. Загорки, $\begin{array}{ll}\text { I. О. Кириченка, } & \text { В. М. Можаровського, }\end{array}$ I. C. Руснака, Р. I. Тимошенка та ін., де основну увагу сконцентровано на проблемах забезпечення національної безпеки та оборони України, боєздатності військ (сил), і зокрема, формуванні та нарощуванні кадрового потенціалу ЗСУ. Питанням дослідження якості вищої військової освіти присвячені роботи таких військових учених-педагогів i психологів: А. О. Вітченка, В. І. Осьодла, С. М. Салкуцана,

В. М. Телелима,

В. І. Свистуна, розглядаються теоретичні та методологічні засади забезпечення якості освіти на основі застосування компетентнісного підходу, впровадження в освітній процес інноваційних педагогічних технологій та сучасних методів 
моніторингу результатів навчання у вищій військовій школі.

Метою статті $\epsilon$ розроблення теоретичних аспектів формування кадрового потенціалу Збройних Сил України в системі вищої військової освіти на основі аналізу вітчизняного та європейського досвіду.

Виклад

основного

матеріалу. Проведене в рамках комплексного огляду сектору безпеки і оборони оцінювання стану воєнної безпеки держави, а також набутий досвід участі ЗСУ в антитерористичній операції сприяли розробленню відповідних програмних документів та внесенню певних змін у чинну законодавчу базу. Передусім це стосується введення в дію Указами Президента України_документів оборонного планування: СОБ та ДПР ЗСУ.
Так, у СОБ визначено стратегічні й оперативні цілі оборонної реформи та шляхи їх досягнення. Зокрема, щодо збільшення спроможностей сил оборони до рівня, що дасть змогу забезпечити виконання завдань оборони держави i відновлення іiі територіальної цілісності, активізації участі в реалізації Спільної безпекової і оборонної політики Європейського Союзу та активне співробітництво 3 НАТО 3 досягненням критеріїв, необхідних для набуття повноправного членства в Організації Північноатлантичного договору [1]. Однією 3 представлених у СОБ стратегічних цілей розвитку Збройних Сил України, наведених на рис. 1, є "Професіоналізація та створення необхідного військового резерву ЗСУ".

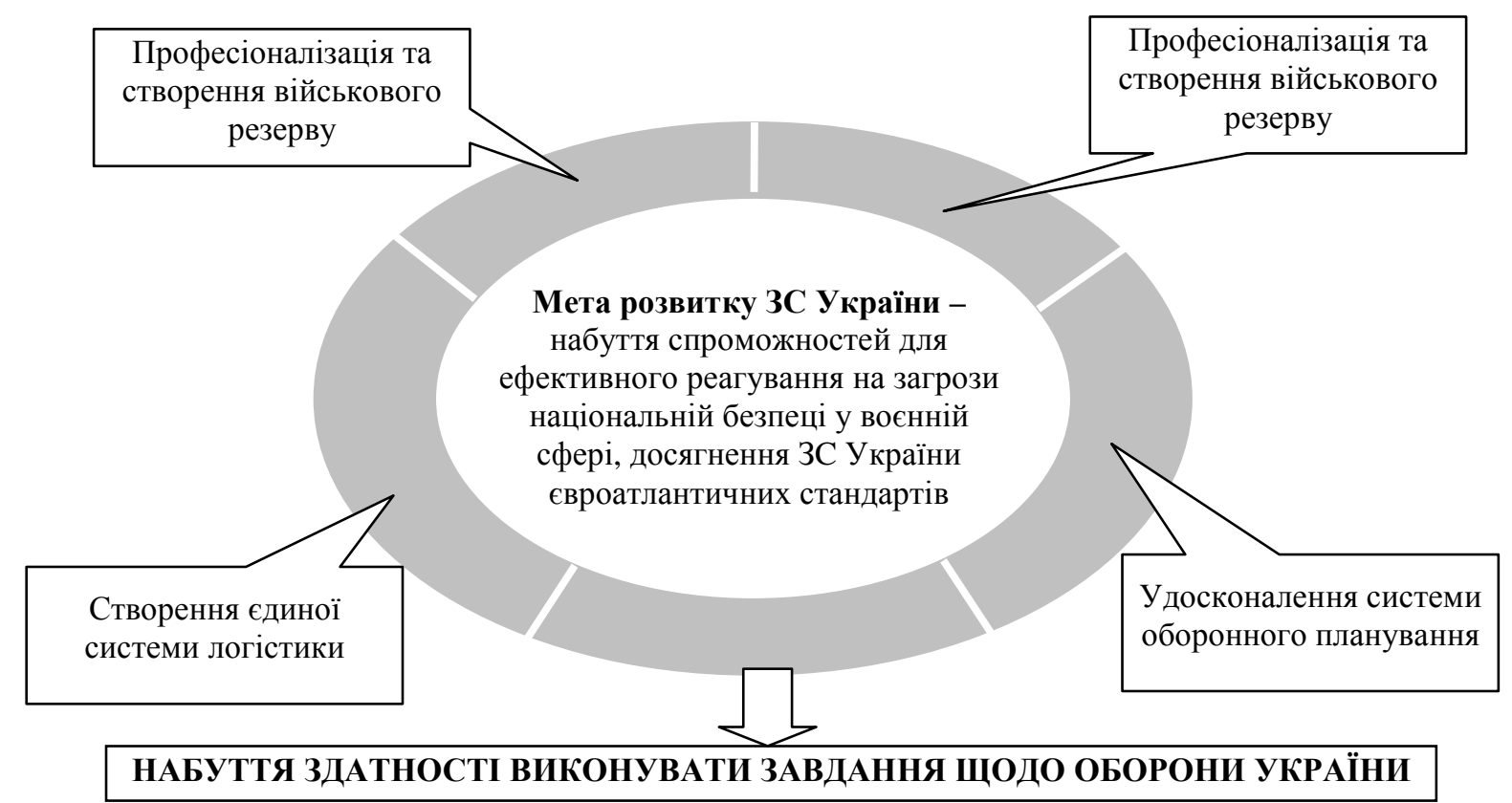

Рис. 1. Стратегічні цілі розвитку Збройних Сил України

Ïї зміст деталізовано у ДПР ЗСУ в рамках оперативної цілі 5.2 - "Удосконалення системи військової освіти та підготовки кадрів", ДЕ викладено низку основних завдань, а саме:

підвищення ефективності роботи системи військової освіти через удосконалення навчально-матеріальної бази, практичного спрямування навчання, впровадження в навчальний процес передових методик підготовки збройних сил держав-членів НАТО; приведення змісту освіти та якості підготовки військових фахівців у відповідність до потреб сил оборони $з$ урахуванням досвіду ATO, бойових дій та міжнародних операцій 3 підтримання миру та безпеки; забезпечення ВВН3 сучасними i перспективними зразками OBT, тренажерами та навчально-тренувальними комплексами;

оптимізація мережі ВВН3 удосконалення їх організаційно-штатної структури;

інтенсифікація участі представників Збройних Сил України у міжнародних навчаннях, тренувальних місіях, тренінгах, освітніх програмах, консультаціях, стажуваннях та інших заходах, насамперед, в рамках програми НАТО "Удосконалення військової освіти (DEEP)";

підвищення ефективності підготовки наукових і науково-педагогічних кадрів для 
якісного забезпечення наукової, науковотехнічної та освітньої діяльності у ВВНЗ та науково-дослідних установах;

підготовка громадян України за програмою підготовки офіцерів запасу за кошти державного бюджету за військовообліковими спеціальностями, що визначають боєздатність підрозділів та військових частин Збройних Сил України;

впровадження в систему освіти технологій дистанційного навчання; розвиток мовної підготовки військовослужбовців ЗС України 3 досягненням ними рівня, достатнього для ефективного впровадження євроатлантичних стандартів, участі в заходах міжнародного оборонного співробітництва, міжнародних операціях із підтримання миру і безпеки [2].

Для ефективної реалізації зазначених завдань необхідно чітке розуміння двох ключових понять - “кадровий потенціал” i “система вищої військової освіти” та їх взаємозв' язків у структурі СВО. Їх сутність, зміст, а також зміст основних складників цих понять на сьогодні чітко не визначені, що потребує, насамперед, проведення відповідного дефінітивного аналізу, уточнення та системного опису понятійного апарату.

Як зауважував відомий німецький воєнний теоретик Карл фон Клаузевіц, "Первая задача всякой теории - это привести в порядок смутные и чрезвычайно спутанные понятия и представления, и лишь условившись относительно названий и понятий, можно надеяться ясно и легко преуспевать в рассмотрении вопросов и при этом питать уверенность, что находишься с читателем на одной и той же точке зрения" [3, С. 39].

Поняття “кадровий потенціал" слід розглядати в контексті загальної категорії “потенціал” (від лат. Potentia - можливість, потужність, сила). У Великому тлумачному словнику сучасної української мови потенціал розглядається як “....приховані здатності, сили для якої-небудь діяльності, що можуть виявитися за певних умов" [4, с. 902]. Відповідно до Концепції військової кадрової політики у Збройних Силах України кадровий потенціал розглядається як “...сукупність кількісно-якісних характеристик кадрів, які визначають їх спроможність вирішувати поточні та перспективні завдання у сфері забезпечення боєздатності Збройних Сил" [5]. Наведене визначення містить два поняття “спроможність" і “боєздатність Збройних Сил”, що потребує певних уточнень. Щодо спроможності, то це загальне поняття несе в собі, у тому числі, відбиток природної здатності, здібності до будь-чого, обдарованості [4, с.1182]. Воно більшою мірою характеризує індивідуальнопсихологічні особливості особистості та $є$ лише однією з умов ефективної діяльності. Але це зовсім не означає, що ця діяльність буде успішною. Тим більш не варто сподіватися на успішність спільної діяльності у сфері забезпечення боєздатності військ, що характеризується певними відмітними ознаками командної роботи, до яких варто віднести такі [6, с.367]: можливість безпосереднього особистісного контакту між учасниками діяльності, у тому числі - обмін діями та інформацією;

наявність єдиної цілі, передбачуваного результату, що відповідають як спільним, так й індивідуальним інтересам;

наявність структур організації спільної діяльності та керівництва;

розподіл процесу спільної діяльності 3-поміж іiі учасників, що зумовлено характером цілі, засобів та умов іiі досягнення, складом і рівнем кваліфікації виконавців;

виникнення у процесі спільної діяльності міжособистісних стосунків, що 3 часом набувають відносно самостійний характер.

Зважаючи на викладене, замість терміну “спроможність", який запозичений 3 військової лексики ЗС США (планування від фінансово-економічних, матеріальнотехнічних та інших спроможностей), більш коректним буде використання терміна "готовність", який більшою мірою характеризує стан військових кадрів. Так, у Великому тлумачному словнику сучасної української мови поняття “готовність" (готовий) визначене як “...стан індивіда, який набув досвіду, досяг високої майстерності, підготувався до чого-небудь" [4, c.194]. У контексті цієї статті поняття “готовність" можна тлумачити як стан особового складу військових підрозділів, частин, з'єднань, який визначається певним рівнем сформованості необхідних професійно важливих якостей i набуттям практичного досвіду щодо їх застосування при виконанні поставлених завдань в умовах мирного і воєнного часу.

Щодо словосполучення "боєздатність збройних сил”, то воно також не $\epsilon$ коректним. Більш відповідним суті проблеми, є поняття “боєздатність військ”. 
Боєздатність військ є визначальним елементом їх бойової готовності і являє собою певний стан здатності військ (авіації, сил флоту) вести бойові дії, виконувати бойові завдання. Бойова здатність залежить від укомплектованості частин і з'єднань, характеру і напруженості бойових дій, втрат і можливості ї швидкого поповнення, підготовленості особового складу, забезпеченості матеріальними засобами тощо [7, c.92].

Відтак, поняття кадровий потенціал можна представити у такій редакції: "Кадровий потенціал - це сукупність кількісноякісних характеристик кадрів, які визначають ïх готовність вирішувати поточні та перспективні завдання у сфері забезпечення боєздатності військ ".

Ще одним ключовим поняттям у контексті цього дослідження є "Система вищої військової освіти". У законі України "Про освіту" поняття "система освіти" представлене як сукупність складників освіти, рівнів i ступенів освіти, кваліфікацій, освітніх програм, стандартів освіти, ліцензійних умов, закладів освіти та інших суб'єктів освітньої діяльності, учасників освітнього процесу, органів управління у сфері освіти, а також нормативно-правових актів, що регулюють відносини між ними. Поняття "освітня діяльнісь” представлене як діяльність суб' єкта освітньої діяльності, яка спрямована на організацію, забезпечення та реалізацію освітнього процесу [8]. У цих поняттях можна виокремити, кілька укрупнених компонентів:

- суб' єкти освітньої діяльності;

- об' єкти освітньої діяльності;

- нормативно-правові акти, що регулюють відносини між суб'єктами та об'єктами освітньої діяльності.

До суб'єктів освітньої діяльності, відповідно до згаданого закону, віднесено фізичну або юридичну особа (заклад освіти, підприємство, установа, організація), що провадить освітню діяльність. Це - мережа BВН3, учасники освітнього процесу: науковопедагогічні та наукові працівники (НПП та НП): слухачі, курсанти, персонал підрозділів управління і забезпечення освітнього процесу ВВН3, органи управління у сфері освіти [8].

До об'єктів освітньої діяльності слід віднести такі складники освіти: рівні та ступені освіти, кваліфікації, освітні програми, стандарти освіти, ліцензійні умови, нормативно-правові акти, якість освіти та освітньої діяльності.
Зважаючи на специфіку освіти у військовій сфері, систему вищої військової освіти можна представити як цілісну сукупність взаємозв'язаних компонентів освітньої діяльності ВВНЗ, що спрямована на організацію, всебічне забезпечення та реалізацію освітнього процесу задля досягнення здобувачами вищої військової освіти визначеного рівня якості освіти. До того ж під якістю освіти слід розуміти відповідність результатів навчання вимогам, встановленим законодавством, відповідним стандартом освіти, де результати навчання являють собою сукупність знань, умінь, навичок, інших компетентностей, набутих особою у процесі навчання за певною освітньо-професійною, освітньо-науковою програмою, які можна ідентифікувати, кількісно оцінити та виміряти. Якість освітньої діяльності визначено як рівень організації, забезпечення та реалізації освітнього процесу, що забезпечує здобуття особами якісної освіти та відповідає вимогам, встановленим законодавством.

Отже, ключовими компонентами вищої військової освіти виступають якість освітньої діяльності та якість освіти, модель взаємозв'язку яких представлено в системі підготовки військових фахівців у ВВНЗ на рис. 2.

У розробленій моделі представлено нові поняття, що, 3-поміж інших, більшою мірою впливають на формування якісних характеристик кадрового потенціалу в системі вищої військової освіти. Серед них найбільш значущими $\epsilon$ такі: забезпечення якості освітньої діяльності та якості освіти; політика гарантування якості підготовки військових фахівців; компетентнісний підхід.

Систему забезпечення якості освіти в Законі України "Про вищу освіту" представлено такими структурними складниками [9]:

система забезпечення вищими навчальними закладами якості освітньої діяльності та якості вищої освіти (система внутрішнього забезпечення якості);

системи зовнішнього забезпечення якості освітньої діяльності вищих навчальних закладів та якості вищої освіти;

система забезпечення якості діяльності Національного агентства із забезпечення якості вищої освіти і незалежних установ оцінювання та забезпечення якості вищої освіти. 


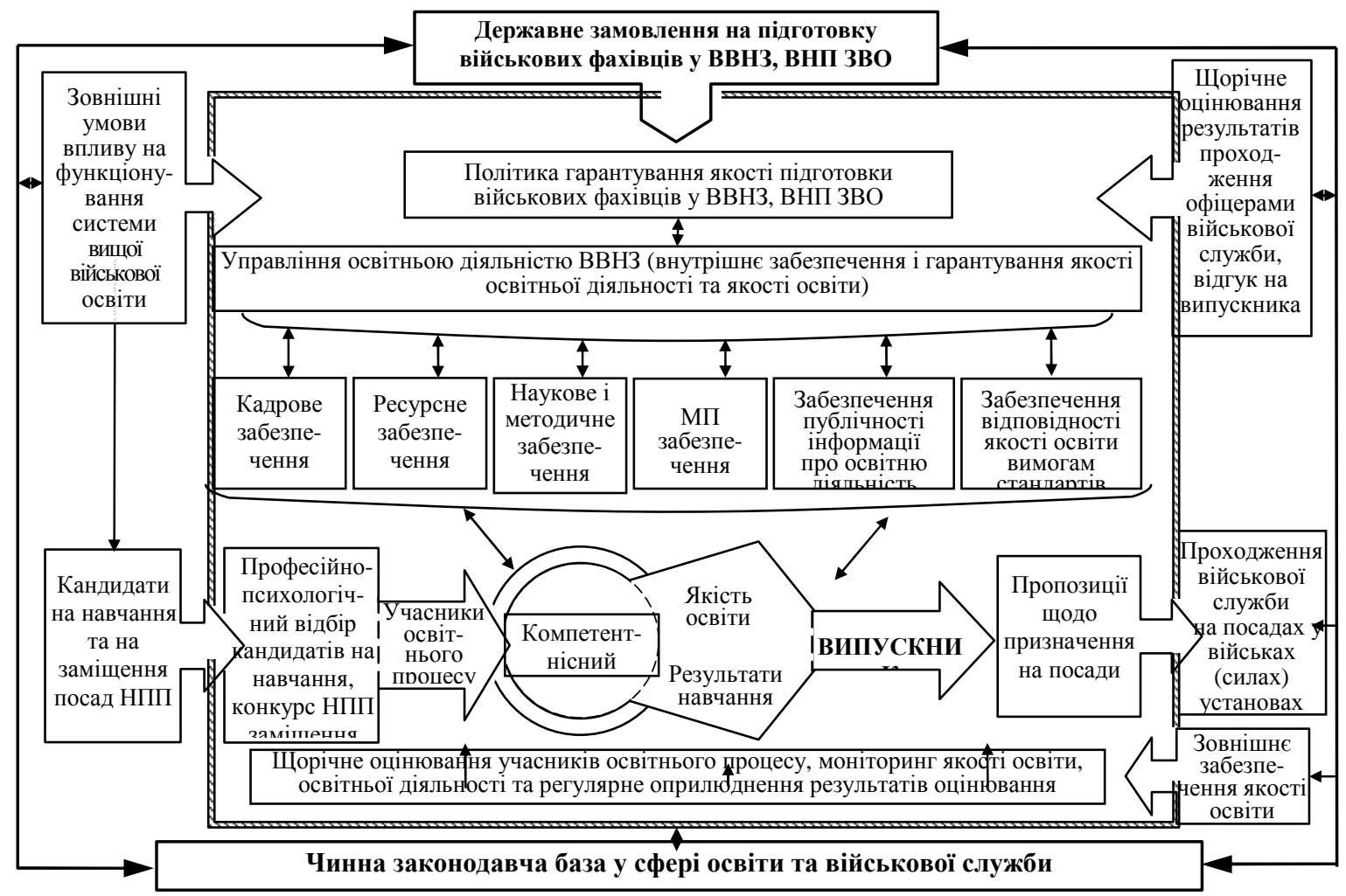

Рис. 2. Модель взаємозв'язку якості освітньої діяльності та якості освіти в системі підготовки

Система внутрішнього забезпечення якості включає:

визначення принципів та процедур забезпечення якості вищої освіти;

здійснення моніторингу та періодичного перегляду освітніх програм;

щорічне оцінювання здобувачів вищої освіти, науково-педагогічних i педагогічних працівників вищого навчального закладу та регулярне оприлюднення результатів таких оцінювань на офіційному веб-сайті вищого навчального закладу, на інформаційних стендах та в будь-який інший спосіб;

забезпечення підвищення кваліфікації педагогічних, наукових і науково-педагогічних працівників;

забезпечення наявності необхідних ресурсів для організації освітнього процесу, у тому числі самостійної роботи студентів, за кожною освітньою програмою;

забезпечення наявності інформаційних систем для ефективного управління освітнім процесом;

забезпечення публічності інформації про освітні програми, ступені вищої освіти та кваліфікації;

забезпечення ефективної системи запобігання та виявлення академічного плагіату у наукових працях працівників вищих навчальних закладів і здобувачів вищої освіти, інших процедур і заходів.

Тобто, йдеться про сутність і зміст складників процесу забезпечення якості освіти (англ. quality assurance education), що цілком відповідає стратегічному курсу України на приведення вищої освіти в Україні відповідно до європейських, а військової - до євроатлантичних стандартів.

У 2000 році в Гельсінкі країнамиучасниками Болонської угоди (включно 3 Україною), була заснована Європейська асоціація забезпечення (гарантування) якості вищої освіти під назвою (European Network for Quality Assurance in Higher Education) організація, що здійснює незалежний контроль якості освіти та освітньої діяльності навчальних закладів.

Довідка. Поняття "Assurance" перекладається з англійської і як "забезпечення" і як "гарантування"; аналогічно, у Великому тлумачному словнику сучасної української мови поняття “забезпечувати” витлумачено як створювати надійні умови для здійснення чогонебудь; гарантувати щось [4, с.281] .

У вітчизняній законодавчій базі термін “гарантування якості освіти” вперше з'явився в Законі України "Про освіту" (Розділ V Забезпечення якості освіти) [8]. Тобто через 17 років після створення ENQA - без жодних коментарів щодо суті, структури і механізмів упровадження цієї категорії в педагогічну практику вищої школи. До того ж поняття "гарантування" введене як одна 3 чотирьох задекларованих у зазначеному законі цілей (ст. 41 розд. V) щодо процесу розбудови та 
функціонування системи забезпечення якості освіти.

У Великому тлумачному словнику сучасної української мови поняття "гарантія" визначено як порука в чомусь, передбачені законом чи угодою (домовленістю) зобов'язання, за яким юридична чи фізична особа відповідає за виконання певної угоди [4, с.173]. Адаптуємо поняття “забезпечення” i "гарантування" до особливостей функціонування системи вищої військової освіти. "Забезпечення", у межах цієї системи, виступає як процес створення необхідних умов для досягнення визначених цілей освіти, а “гарантування" (гарантія) - як порука ВВНЗ за якість освіти та відповідальність за досягнення здобувачами вищої військової освіти певних результатів навчання. Отже, гарантія якості вищої військової освіти у контексті результатів навчання - це порука та відповідальність ВВНЗ щодо виконання зобов'язань 3 підготовки слухачів (курсантів) зі ступенем сформованості визначених компетентностей в кожного 3 них не нижче встановленого рівня [10]. До того ж компетентність являє собою інтегральний показник якості підготовки здобувачів вищої військової освіти як доведена ними готовність до виконання функціональних обов'язків на посаді за призначенням у військах (силах) в умовах мирного і воєнного часу на основі творчого застосування здобутих знань, сформованих навичок та умінь, інших професійно важливих якостей i ціннісних орієнтацій відповідно до стандартів освіти [11, с.75-76].

Більш глобальним поняттям у контексті цього дослідження є політика гарантування якості військової освіти - скоординована діяльність органів законодавчої, виконавчої влади і системи військової освіти стосовно створення і регуляції необхідних умов щодо формування кадрового потенціалу 3СУ 3 визначеним рівнем сформованості в них необхідних компетентностей для успішного вирішення поточних і перспективних завдань у сфері забезпечення боєздатності військ.

3 огляду на викладене, основними шляхами процесу формування кадрового потенціалу у системі вищої військової освіти слід вважати такі:

розроблення нового покоління стандартів освітньої діяльності та вищої освіти з урахуванням стандартів НАТО;

формування та розвиток у здобувачів вищої освіти професійних, світоглядних, морально-бойових якостей громадянинапатріота - захисника Вітчизни; удосконалення якості професійнопсихологічного відбору кандидатів на навчання;

оптимізація змісту освіти на основі впровадження в педагогічну практику розроблених компетентнісно-змістових модулів;

удосконалення системи конкурсного відбору офіцерів на посади педагогічних, науково-педагогічних та наукових працівників;

поглиблення інтеграції військової освіти 3 бойовою та спеціальною підготовкою військ, проведення спільних заходів із залученням до цього інструкторів із держав-членів НАТО; впровадження інформаційних, інформаційно-комунікаційних, особистісно орієнтованих педагогічних технологій i технологій дистанційного навчання в освітню практику ВВНЗ;

створення необхідних умов для забезпечення якості освіти та освітньої діяльності.

Висновки. Військова освіта $\epsilon$ специфічною складовою загальнодержавної системи освіти України. 3 неї розпочинається професіоналізація i нарощування кадрового потенціалу Збройних Сил України, що значно впливає на зміцнення обороноздатності держави, забезпечення захищеності від реальних та потенційних загроз іiі державного суверенітету, теріториальної цілісності, демократичного конститутаційного ладу та інших національних інтересів України.

Розглуті у статті теоретичні аспекти формування кадрового потенціалу Збройних Сил України в системі вищої військової освіти $€$ основою забезпечення якості освітньої діяльності ВВНЗ та якості підготовки здобувачів освіти тактичного, оперативнотактичного та оперативно-стратегічного рівнів. Якісна військова освіта, високий рівень фахової підготовки військових фахівців $\epsilon$ одним 3 пріоритетів забезпечення національної безпеки України, що цілком відповідає нормам діючої нормативно-правової бази 3 питань оборонного планування. Гарантом якості підготовки військових фахівців мають виступати ВВНЗ як основний суб'єкт системи військової освіти.

Напрями подальших досліджень. Розроблення концепції формування кадрового потенціалу Збройних Сил України в системі вищої військової освіти.

СПИСОК ВИКОРИСТАНОЇ ЛІТЕРАТУРИ 
1. Стратегічний оборонний бюллетень // Указ Президента України від 06.06.2016 № 240/2016.

2. Державна Программа розвитку Збройних Сил України на період до 2020 року // Указ Президента України від 22.03.2016 № 73/2017.

3. Клаузевиц К. О войне / К. Клаузевиц.- М.: Эксмо; СПб.: Terra Fantastica, 2003. - 864 с.

4. Великий тлумачний словник сучасної української мови / Уклад. і голов. ред. В. Т. Бусел. - К.; Ірпінь: ВТФ “Перун”, 2001. - 1440 с.

5. Концепції військової кадрової політики у Збройних Силах України на період до 2020 року // (Затверджена наказом Міністерства оборони України № 342 від 26.06.2017)

6. Психология. Словарь / Под общ. ред.

А. В. Петровского, М. Г. Ярошевского. - 2-е изд., испр. и доп.- М.: Политиздат, 1990. - 494 с.

7. Военный энциклопедический соварь / Пред. гл. ред. комиссии Н.В. Огарков - М.: Воениздат, 1983 -863 c.
8. Про освіту: Закон України від 05.09.2017 №2145VIII (Відомості Верховної Ради (ВВР), 2017, № 38-39, ст. 380).

9. Закон України “Про вищу освіту” від 01.07.2014 № 1556-VII [Електронний ресурс]. - Режим доступу: http://zakon4.rada.gov.ua/laws/show/155618/page2.

10. Зельницький А. М., Концептуальні засади гарантування якості підготовки майбутніх офіцерів Збройних Сил України у вищих військових навчальних закладах. Вісник Черкаського університету. Серія пед. науки. - Ч., 2017. - № 6. - С. 71-83.

11. Моніторинг якості підготовки військових фахівців у вищих військових навчальних закладах та військових навчальних підрозділах вищих навчальних закладів Збройних Сил України: наук.-метод. посіб. / А. М. Зельницький, О. А. Заболотний, Ю. І. Приходько та ін.; за заг. ред. І. В. Толока.: ХНУПС, 2017. -120 с.

Стаття надійшла до редакції 11.07.2018

Заболотный О. А., к.воен.н., доцент;

Зельницкий А. Н., к.пед.н., профессор;

Олиферук В. Н.

Центр военно-стратегических исследований Национального университета оборони Украины имени Ивана Черняховского, Киев

Формирование кадрового потенциала Вооруженных Сил Украины в системе высшего военного образования: теоретические аспекты

Резюме. В статье рассмотрены теоретические аспекты формирования кадрового потенциала Вооруженных Сил Украины и качества подготовки, переподготовки и повышения квалификации офицерских кадров в системе высшего военного образования.

Ключевые слова: кадровый потенциал Вооруженных Сил Украины; система высшего военного образования; качество подготовки офицерских кадров.

\section{O. Zabolotnyi, PhD (Military), assistant professor;}

A. Zelnytskyi, PhD (Pedagogical Sciences), professor;

\section{Oliferuk}

Center for Military and Strategic Studies of the National Defence University of Ukraine named after Ivan Cherniakhovskyi, Kyiv

Formation of Armed Forces of Ukraine's Professional Potential in Higher Military Education System: Theoretical Aspects

Resume. The article deals with theoretical aspects of Armed Forces of Ukraine's Professional Potential formation and its training quality, retraining and advanced training of officers in the system of higher military education.

Keywords: Armed Forces of Ukraine's professional potential; system of higher military education; officers' training quality. 